\title{
An assessment of ozone mini-hole representation in reanalyses over the Northern Hemisphere
}

\author{
Luis F. Millán ${ }^{1}$ and Gloria L. Manney ${ }^{2,3}$ \\ ${ }^{1}$ Jet Propulsion Laboratory, California Institute of Technology, Pasadena, California, USA \\ ${ }^{2}$ NorthWest Research Associates, Socorro, New Mexico, USA \\ ${ }^{3}$ New Mexico Institute of Mining and Technology, Socorro, New Mexico, USA \\ Correspondence to: Luis F. Millán (luis.f.millan@jpl.nasa.gov)
}

Received: 12 April 2017 - Discussion started: 2 May 2017

Revised: 8 July 2017 - Accepted: 10 July 2017 - Published: 4 August 2017

\begin{abstract}
An ozone mini-hole is a synoptic-scale region with strongly decreased total column ozone resulting from dynamical processes. Using total column measurements from the Ozone Monitoring Instrument and ozone profile measurements from the Microwave Limb Sounder, we evaluate the accuracy of mini-hole representation in five reanalyses. This study provides a metric of the reanalyses' ability to capture dynamically driven ozone variability. The reanalyses and the measurements show similar seasonal variability and geographical distributions of mini-holes; however, all of the reanalyses underestimate the number of mini-holes and their area, and in many reanalyses their location displays an eastward bias. The reanalyses' underestimation of mini-hole number ranges from about 34 to about $83 \%$. The mini-hole vertical representation in the reanalyses agrees well with that in the MLS measurements and, furthermore, is consistent with previously reported mechanisms for mini-hole formation. The skill of the reanalyses is not closely tied to the ozone fields assimilated, suggesting that the dynamics of the reanalysis models are more important than the assimilated ozone fields to reproducing ozone mini-holes.
\end{abstract}

\section{Introduction}

Since early ozone measurements (Dobson et al., 1929), it has been known that the total column ozone is characterized by day-to-day local fluctuations that are correlated with the passing of synoptic weather systems. Meetham and Dobson (1937) found a significant correlation between the total column ozone and stratospheric temperature and potential tem- perature, as well as the density and height of the tropopause. Reed (1950) studied the relative importance of horizontal advection and vertical motion to producing such fluctuations and the manner in which those two mechanisms combine to produce the ozone-weather relationships.

Events with very low total ozone columns were named ozone mini-holes by Newman et al. (1988) because of their rapid ozone decline and their synoptic scale, which was in contrast to the slow ozone decline and planetary scale of the Antarctic ozone hole. These events are found mainly throughout midlatitudes in both hemispheres (e.g., James, 1998a, b; Hood et al., 2001). Unlike the well-known Antarctic ozone hole, mini-holes are mainly driven by dynamical atmospheric processes rather than photochemical processes. As pointed out by Reed (1950), they result from a combination of uplift of air and horizontal advection. Assuming net divergence, local uplift of the air increases the amount of the column occupied by ozone-poor tropospheric air (e.g., Salby and Callaghan, 1993; Petzoldt et al., 1994; Teitelbaum et al., 1998; Hood et al., 2001; Canziani et al., 2002) while horizontal advection brings ozone-poor air into the column through poleward transport around the tropopause, through equatorward transport of polar air around the middle of the stratosphere, or through a combination of the two (e.g., Vaughan and Price, 1991; Orsolini et al., 1995; Peters et al., 1995; James et al., 2000; Allen and Nakamura, 2002; James and Peters, 2002; Mangold et al., 2009).

As an example, Fig. 1 shows the mini-hole event observed over the UK on 19 January 2006. On this day, a record low total ozone column of 177 DU was observed at Reading (where the long-term mean is about $310 \mathrm{DU}$ at this time of year) as 


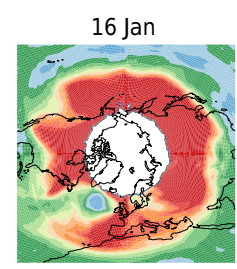

19 Jan
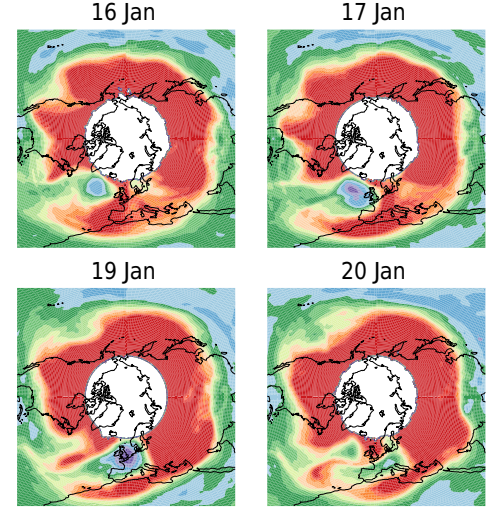

20 Jan
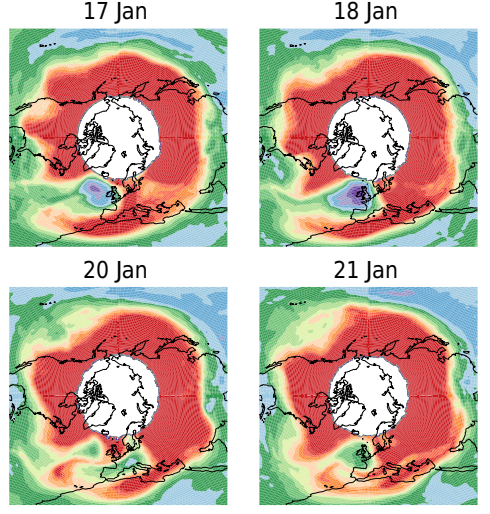

Figure 1. OMI total ozone column for 16-21 January 2006. The data over the pole are missing due to the lack of UV backscattering. Red/purple indicate relatively high/low values of OMI total ozone column.

well as low total ozone columns over other northwest European stations (Keil et al., 2007). Figure 1 also shows the same region a few days before and after the event to illustrate the transient nature of this phenomenon.

Reanalyses from data assimilation systems provide globally gridded high-resolution meteorological fields based on an optimized combination of general circulation models and observational data. Reanalyses from the latest generation also provide fields of assimilated ozone but use different ozone inputs and assimilation methods (e.g., Fujiwara et al., 2017). In this paper, the accuracy of mini-hole representation is used as a metric to assess the reanalyses' ability to capture dynamically driven ozone variability. We used five of the most recent high-resolution reanalyses: the European Centre for Medium-Range Weather Forecasts (ECMWF) ERA-Interim reanalysis, the National Centers for Environmental Prediction Climate Forecast System Reanalysis (CFSR), the Japanese 55-year Reanalysis (JRA-55), the Modern-Era Retrospective Analysis for Research and Applications (MERRA), and its successor MERRA-2. We evaluate the mini-hole representation comparing the mini-hole events' area, distance, and orientation with respect to the events found in the Ozone Monitoring Instrument (OMI) data (Levelt et al., 2006). Further, we use vertical profiles of ozone and temperature from the Aura Microwave Limb Sounder (MLS) (Waters et al., 2006), as well as derived meteorological products (DMPs) (Manney et al., 2007) and detailed tropopause information from the JEt and Tropopause Products for Analysis and Characterization (JETPAC) package (Manney et al., 2011), to study the vertical structure and relationships to the tropopause of the mini-holes in reanalyses and satellite data. Dynamically induced ozone mini-holes can produce extreme ozone deficits that result in significant local increases in surface UV; thus our ability to predict and characterize these events is important to human health. Because of the combination of dynamical and transport processes that produce mini-holes, they are a stringent test of the representation of upper troposphere-lower stratosphere (UTLS) dynamics in the reanalyses. Understanding of the reanalyses' ability to reproduce these events can thus be used to guide improvements in the models and data assimilation systems, and hence in our ability to forecast such events. This paper is organized as follows: Sect. 2 gives an overview of the satellite data and the reanalyses used in this study. Section 3 describes the minihole definition used. Sections 4 and 5 show comparisons with OMI and MLS, respectively. Lastly, Sect. 6 provides a summary.

\section{Data}

In this section a description is given of the observational data as well as the reanalyses used. We use observations from the NASA's Earth Observing System (EOS) Aura satellite, launched on July 2004 into a polar sun synchronous orbit. In particular, we use OMI and MLS data. As mentioned before, we use the following meteorological reanalyses: MERRA, MERRA-2 ERA-Interim, JRA-55, and CFSR.

\subsection{Aura OMI}

Aura OMI (Levelt et al., 2006) is a nadir-viewing pushbroom spectrometer designed to monitor ozone and other trace gases, as well as aerosols, cloud top heights, and UV irradiance at the surface. It measures ultraviolet/visible solar backscatter radiation with a high spectral resolution over the entire wavelength range from 270 to $500 \mathrm{~nm}$. Total column ozone is derived using two distinct algorithms: the Total Ozone Mapping Spectrometer (TOMS) algorithm and the differential optical absorption spectroscopy (DOAS) algorithm.

The OMI-TOMS algorithm is described by Bhartia and Wellemeyer (2002). This algorithm is based on the TOMS version 8 algorithm that has been used to estimate total ozone columns from four TOMS instruments since 1978. The OMIDOAS algorithm is described by Veefkind et al. (2006). Both datasets have been extensively validated (Balis et al., 2007; Kroon et al., 2008; McPeters et al., 2008; Antón et al., 2009), indicating agreement within $2 \%$ with ground-based and airborne measurements. In this study we use the OMI-TOMS algorithm. In particular, we use the level 3 files (OMTO3d, V003) with a $1^{\circ}$ by $1^{\circ}$ resolution.

\subsection{Aura MLS}

Aura MLS (Waters et al., 2006) is a small radio telescope whose mission objective is studying ozone, air quality, and climate (Schoeberl et al., 2006). It vertically scans the Earth's limb from the surface to $\sim 95 \mathrm{~km}$, measuring thermal microwave emission with a spectral range varying from 118 to $2500 \mathrm{GHz}$. These radiances are inverted using a tomographic optimal estimation retrieval algorithm (Livesey et al., 
2006), producing $\sim 3500$ vertical profiles per day of temperature, cloud ice, and 16 atmospheric trace gases. In this study we use version 4.2 temperature and ozone data filtered as described in the MLS data quality document (Livesey et al., 2017). This dataset provides ozone profiles from 261 to $0.02 \mathrm{hPa}$ with vertical resolution of around $3 \mathrm{~km}$ in the upper troposphere and stratosphere, precision varying from $0.03 \mathrm{ppmv}$ at $261 \mathrm{hPa}$ to $0.2 \mathrm{ppmv}$ at $1 \mathrm{hPa}$, and stratospheric accuracy better than $10 \%$. Temperature is provided from 261 to $0.001 \mathrm{hPa}$ with vertical resolution varying from around $4.5 \mathrm{~km}$ in the upper troposphere to $3.6 \mathrm{~km}$ in the middle stratosphere, precision around $1 \mathrm{~K}$ at these levels, and accuracy better than $2.5 \mathrm{~K}$.

Ozone version 2.2 was extensively validated (Jiang et al., 2007; Froidevaux et al., 2008; Livesey et al., 2008), indicating agreement at the 5 to $10 \%$ level with satellite, balloon, aircraft, and ground-based ozone data. Above the tropopause, version 4.2 is very similar to version 2.2 , so past validation results still hold. In the upper troposphere, version 4.2 has reduced spurious vertical oscillations found in previous versions, particularly at midlatitudes. Also, version 4.2 has reduced the ozone retrieval sensitivity to thick clouds through changes in the forward model representation of cloud impacts on the MLS radiances (Livesey et al., 2017). Hubert et al. (2016) assessed the long-term stability, overall bias, and short-term variability of several satellite ozone records using ground-based data and found MLS version 3.3 to be stable in the entire stratosphere (to within $1.5 \% \mathrm{decade}^{-1}$ in the middle stratosphere). Version 2.2 temperature data were extensively validated (Schwartz et al., 2008), indicating agreement at the $2.5 \mathrm{~K}$ level with satellite and radiosonde data, as well as with reanalysis fields. Version 4.2 is similar to version 2.2 so, again, the validation still holds (Livesey et al., 2017).

\subsection{Reanalyses}

The reanalyses used in this study are MERRA and MERRA2 (Rienecker et al., 2011; Bosilovich et al., 2015; Wargan et al., 2017), ERA-Interim (Dee et al., 2011), CFSR (Saha et al., 2010), and JRA-55 (Kobayashi et al., 2015). A detailed overview of these reanalyses is given by Fujiwara et al. (2017). Briefly, MERRA, MERRA-2, and CFSR use a 3D-FGAT ("first guess at the appropriate time"; Lawless, 2010) assimilation scheme, while ERA-Interim and JRA-55 use an incremental 4D-Var (Courtier et al., 1994) approach. Overall, all reanalyses use the same conventional data (e.g., surface records, radiosonde profiles, and aircraft measurements); there are, however, many differences in the satellite data usage. In particular, the ozone inputs vary widely (see Fig. 2): only MERRA-2 and ERA-Interim assimilate OMI and MLS ozone data. Only MERRA-2 assimilates MLS temperature retrievals at pressures less than or equal to $5 \mathrm{hPa}$. There are also differences in the horizontal and vertical grids, lid heights, and models' ozone treatment among the reanalyses. Table 1 summarizes these specifications. An assess- ment of the upper tropospheric and stratospheric reanalysis ozone fields can be found at Davis et al. (2017). Note that JRA-55 does not assimilate measurements directly; first, ozone concentrations are estimated using a chemistry transport model and then nudged to the total column ozone observations (Kobayashi et al., 2015; Fujiwara et al., 2017).

To ease the comparison of the reanalysis fields against the OMI data, the reanalysis data were first interpolated to the OMI measurement times and then interpolated onto the OMI latitude-longitude grid, that is to say, a $1^{\circ}$ latitude by a $1^{\circ}$ longitude spacing. In addition, gaps in the OMI data (for example, polar winter periods) were identified and masked out in the interpolated reanalysis fields to ensure that the same regions were compared day by day.

To ease comparison with MLS, we use the MLS DMPs (Manney et al., 2007). These DMPs are meteorological and derived meteorological fields interpolated to the MLS measurement locations (in time and space) computed within the JETPAC package (Manney et al., 2011), which also characterizes UTLS jets and multiple tropopauses. In particular, for this study we use ozone, temperature, equivalent latitude (EqL), and the JETPAC tropopause characterization. $\mathrm{EqL}$ is a quasi-Lagrangian coordinate widely used in stratospheric studies (e.g., Butchart and Remsberg, 1986). Simply put, EqL is the latitude that would enclose the same area as the corresponding potential vorticity contours. Thermal tropopauses are determined from the reanalysis temperature profiles using the World Meteorological Organization (WMO) definition (e.g., Homeyer et al., 2010), that is to say, where the temperature lapse rate falls below $2 \mathrm{~K} \mathrm{~km}^{-1}$ for at least $2 \mathrm{~km}$. Similarly, additional tropopauses are identified above the primary tropopause (e.g., Randel et al., 2007; Añel et al., 2008; Manney et al., 2011).

\section{Ozone mini-holes: definition and analysis}

Several mini-hole definitions can be found in the literature: Hood et al. (2001) used a constant threshold of 215 DU, while Bojkov and Balis (2001) used 220 DU. James (1998a) used thresholds computed by subtracting 70 DU from zonally and meridionally averaged monthly means, while Iwao and Hirooka (2006) chose to subtract 80 DU. Koch et al. (2005) defined a threshold based on monthly mean values minus 1 standard deviation, while Martínez-Lozano et al. (2011) used monthly mean values minus 2 times the standard deviation. In addition to these thresholds, other constraints have been applied: Bojkov and Balis (2001) only considered as miniholes those events with area greater than $500000 \mathrm{~km}^{2}$ in the 40-65 latitude regions, while James (1998a) only considered events found over at least a $5.533^{\circ}$ latitude by $5.625^{\circ}$ longitude region, that is, covering an area equivalent to the ones found by Bojkov and Balis (2001).

Figure 3 shows the geographical distribution of mini-hole events found in the OMI data during 2005 using different 
Table 1. Basic specifications of the reanalysis forecast models.

\begin{tabular}{|c|c|c|c|c|c|}
\hline Reanalyses & Grid & No. levels & Lid height & Reference & Ozone model \\
\hline MERRA & $0.66^{\circ} \times 0.5^{\circ}$ & 72 & $0.01 \mathrm{hPa}$ & Rienecker et al. (2011) & Rienecker et al. (2008) \\
\hline MERRA-2 & $0.625^{\circ} \times 0.5^{\circ}$ & 72 & $0.01 \mathrm{hPa}$ & Bosilovich et al. (2015) & Rienecker et al. (2008) \\
\hline ERA-Interim & $0.75^{\circ} \times 0.75^{\circ}$ & 60 & $0.1 \mathrm{hPa}$ & Dee et al. (2011) & $\begin{array}{l}\text { Cariolle and Déqué (1986), } \\
\text { Cariolle and Teyssèdre (2007) } \\
\text { and Dethof and Hólm (2004) }\end{array}$ \\
\hline CFSR & $0.5^{\circ} \times 0.5^{\circ}$ & 64 & $\sim 0.26 \mathrm{hPa}$ & Saha et al. (2010) & McCormack et al. (2006) \\
\hline JRA-55 & $0.56^{\circ} \times 0.56^{\circ}$ & 60 & $0.1 \mathrm{hPa}$ & Kobayashi et al. (2015) & Shibata et al. (2010) \\
\hline
\end{tabular}

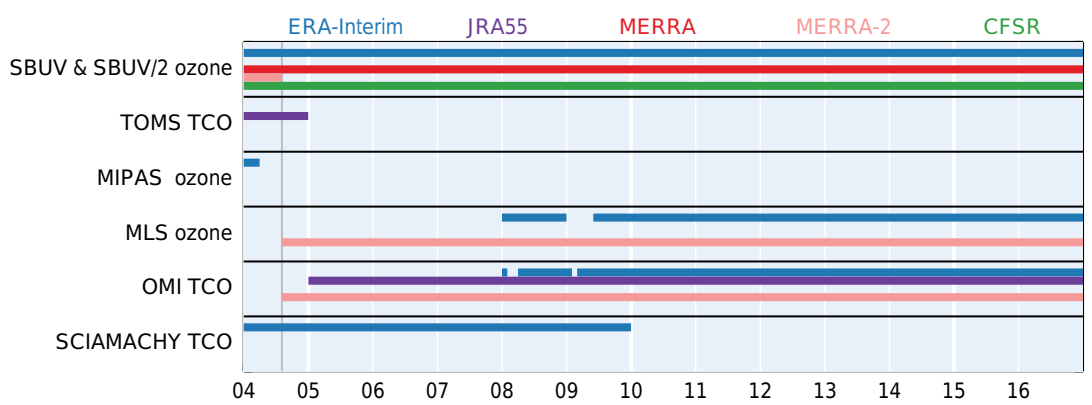

Figure 2. Timelines of ozone observations (vertical profiles and total column ozone - TCO) assimilated during the MLS/OMI period by the ERA-Interim (blue), JRA-55 (purple), MERRA (dark red), MERRA-2 (light red), and CFSR (green) reanalysis systems. Based on Fig. 9 from Fujiwara et al. (2017). Gray vertical line indicates the start of the OMI and MLS measurements. Note that JRA-55 does not assimilate OMI TCO directly; first, ozone concentrations are estimated using a chemistry transport model and then nudged to the TCO observations (Kobayashi et al., 2015; Fujiwara et al., 2017).

mini-hole definitions: Fig. 3a shows the mini-hole geographical distribution found using a constant threshold of $220 \mathrm{DU}$; Fig. $3 \mathrm{~b}$ shows the events found using thresholds computed by subtracting $70 \mathrm{DU}$ from the monthly mean; Fig. 3c shows the events found using thresholds computed by subtracting 2 times the standard deviation from the monthly mean; Fig. 3d shows the events found when the total column ozone value is less than $25 \%$ below the monthly mean. In each case, we use a flood filling algorithm - an algorithm that determines pixels meeting a threshold value in a 2-D array - in the region of the total column ozone anomaly to find the adjacent pixels that were below the chosen threshold. Note than no additional constraints (size of the event or geographical position) were applied. Because of this, there are a disproportionate number of events in the Southern Hemisphere compared to the Northern Hemisphere in panels (a), (b), and (d): most of these events are related to the Antarctic ozone hole; that is to say, they are due to heterogeneous chemistry and not driven by dynamics. Hence, we will not analyze them in this paper.

As shown in Fig. 3, the occurrence frequency of miniholes, as well as their geographical distribution, depends strongly on the definition used. In this study, we chose to define mini-hole events as regions where the total column ozone value is less than $25 \%$ below the monthly mean. Monthly means were used as opposed to climatological monthly means to avoid biasing the number of events by any long-term trend in ozone or by interannual variability in the planetary-scale "background" ozone values. We choose this definition because a constant - below 220 DU - threshold would identify more events in those months when the background ozone levels are naturally low. For example, OMI midlatitude mean total column ozone varied from $\sim 390 \mathrm{DU}$ around March to $\sim 290 \mathrm{DU}$ around mid-October. Hence, using a constant $220 \mathrm{DU}$ threshold would identify more events during fall than in spring. An analogous argument applies to a fixed difference threshold, e.g., 70 DU less than the monthly mean. In a similar manner, the standard deviation threshold identifies many events in the tropics where ozone levels and variability are naturally low.

In addition to identifying the mini-holes in OMI and the reanalysis fields, the algorithm matches the events found in the reanalyses with the ones found in OMI. Within each day's events, the algorithm checks whether the events found in OMI and the reanalysis overlap; if they do not, the algorithm finds the closest one within a distance of $2000 \mathrm{~km}$. Although this is a simple algorithm, visual inspection of many days showed it to be appropriate.

\section{Comparison with OMI}

Figure 4 compares the mini-hole events per month found in OMI and the reanalysis fields during 2005 to 2014. Figure 4a 


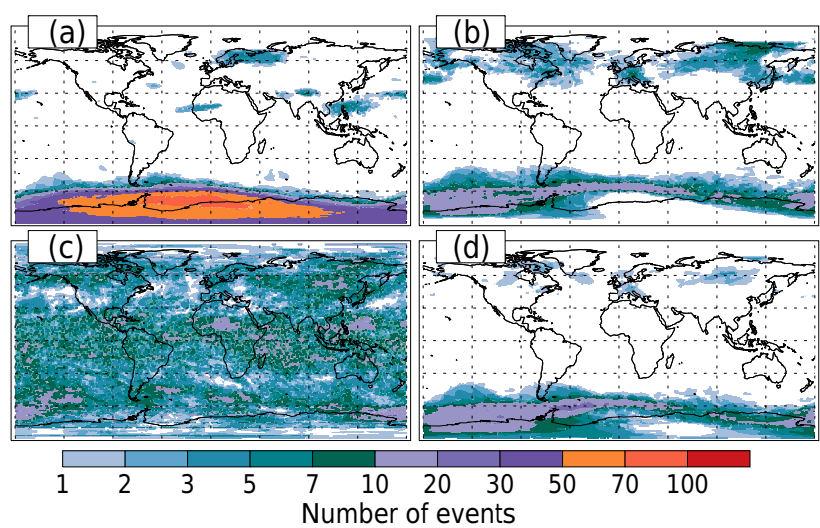

Figure 3. Geographical distribution of mini-hole events for OMI data in 2005. Four different mini-hole definitions are compared: (a) using a constant threshold of $220 \mathrm{DU}$, (b) using as thresholds the monthly mean minus $70 \mathrm{DU}$, (c) using as thresholds the monthly mean minus 2 times its standard deviation, and (d) the percentage threshold discussed in the text. Red/blue indicate relatively high/low number of events counts.

shows a time series of all the events found regardless of their area, while Fig. 4b shows only events with area greater than $200000 \mathrm{~km}^{2}$. Clearly, the reanalyses are underestimating the frequency of the smaller events. Historically, the term minihole refers to synoptic-scale events, and hence these subsynoptic events have been regarded as hindrance by James (1998a) and filtered out either by interpolating to synopticscale grids or by only analyzing events greater than a particular area (James, 1998a; Bojkov and Balis, 2001). In this study, we will only analyze events with areas greater than $200000 \mathrm{~km}^{2}$ to avoid these subsynoptic-scale events. We note an increase in the number of subsynoptic-scale events after 2010; however, a detailed study of these events is beyond the scope of this paper.

Figure $4 \mathrm{c}$ shows that the mini-hole events' seasonal variations found in reanalyses and in the observations are similar. In OMI and the reanalysis fields, mini-hole events are most frequent during winter when the atmosphere is more dynamically active. Synoptic-scale storms are strongest and most common during midwinter, resulting in powerful storm tracks that uplift the air - which, assuming net divergence, increases the amount of the column occupied by ozone-poor tropospheric air - which is one of the mechanisms responsible for mini-hole genesis (James, 1998a; Hood et al., 2001). Despite the similarities between the representation of miniholes in reanalyses and OMI data, differences exist among their seasonal variations: the most noticeable is that all reanalyses underestimate the number of mini-hole events, with the underestimation ranging from $34 \%$ less for ERA-Interim up to $83 \%$ less for JRA-55. Further, the events found in OMI display a mildly positively skewed distribution (the increase in number of events between September and January is rapid while the decay between January and March is slow), as op-
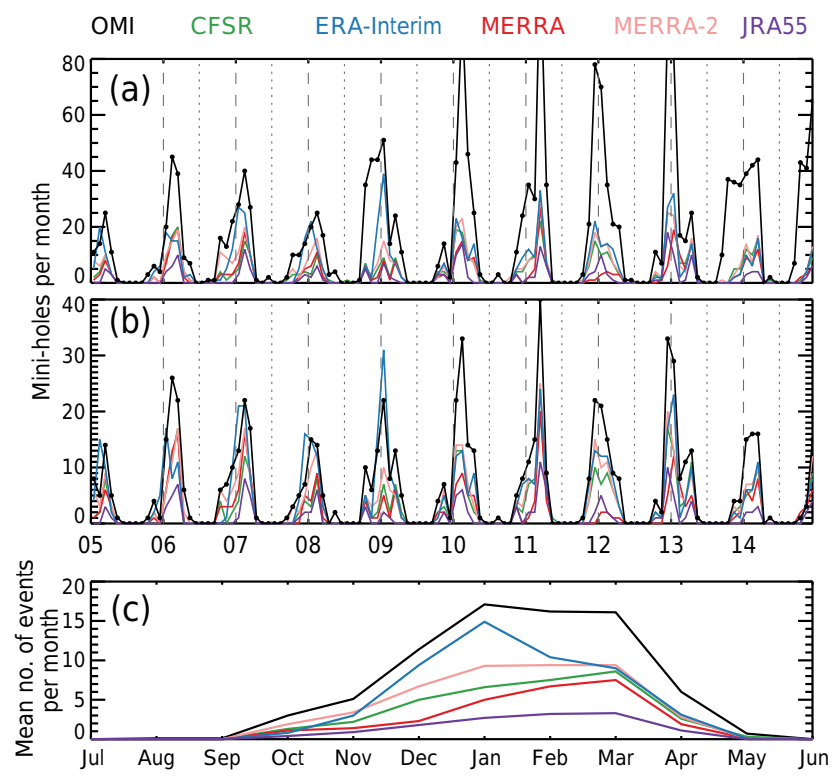

Figure 4. Mini-hole events per month during 2005-2014 in the Northern Hemisphere as found in OMI data and reanalysis fields (black, green, blue, red, pink, and purple lines represent OMI, CFSR, ERA-Interim, MERRA, MERRA-2, and JRA-55, respectively). Panel (a) shows all the events while (b) displays only the events with area greater than $200000 \mathrm{~km}^{2}$. Dashed vertical lines indicate the beginning of each January; dotted vertical lines show the beginning of each July. Panel (c) shows the mean number of minihole events in a given month (during 2005-2014) for events with area greater than $200000 \mathrm{~km}^{2}$.

posed to the events found in the reanalyses (except for ERAInterim), which display a distinctly negatively skewed distribution (the increase in number of events between September and March is slow, followed by a rapid decay in spring).

The geographical count of mini-hole events is shown in Fig. 5. Although the reanalyses underestimate the number of mini-hole events, the mini-hole count morphologies are similar, with mini-holes occurring most frequently over the North Atlantic storm tracks. This region of maximum activity has been identified before by James (1998a) and Hood et al. (2001). This, in addition to the increase in mini-hole activity during winter, suggests that all reanalyses simulate the storm track influence upon mini-hole genesis to some degree.

Using the matching algorithm described above, it is possible to compute the distance between the matching events as well as to study their areas. Figure 6 compares the distance between the events found in the reanalysis fields and OMI data, as well as their area fractions. Ideally, one would like to have a delta function at zero when comparing the distance between events. The closest reanalysis to display this behavior is MERRA-2, which shows a narrower distribution centered around $75 \mathrm{~km}$; the other reanalyses display positively skewed distributions with the majority of values lying between 75 and $300 \mathrm{~km}$. With respect to their area frac- 

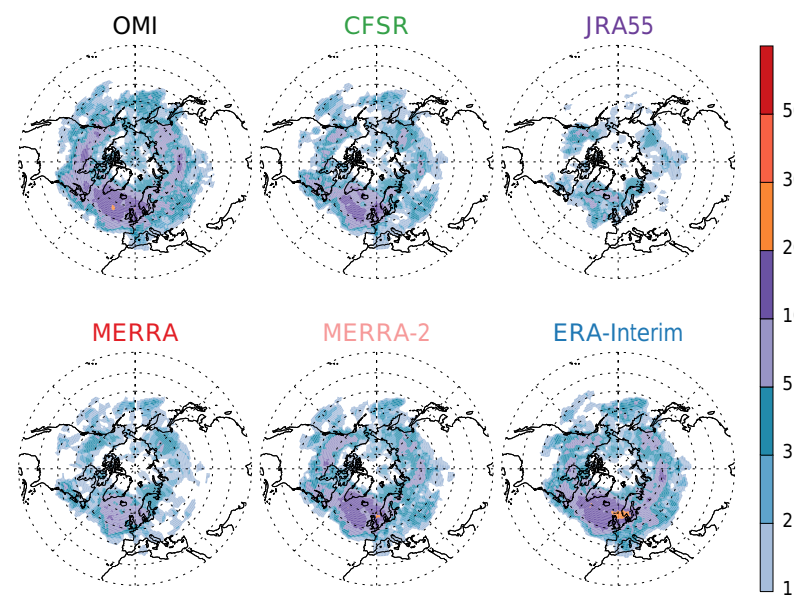

Figure 5. Geographical distribution of mini-hole events during 2005-2014 as found in OMI and reanalysis fields. Red/blue indicate relatively high/low number of events counts.

tions, ideally one would like to see a delta function at one; again, only MERRA-2 displays a narrow distribution, in this case near 0.8 . Overall, the other reanalyses usually underestimate the area of the mini-hole events. The slightly better performance in MERRA-2 may be related to the fact that this is not an independent comparison: MERRA-2 assimilates OMI total column ozone data throughout the comparison period. Note that ERA-Interim assimilates OMI data after 2008. However, CFSR only assimilates SBUV/2 ozone and performs similarly to ERA-Interim, suggesting that the dynamics produced by the reanalyses are more important than the assimilated ozone fields for reproducing mini-holes.

Figure 6 also shows the number of events found in each dataset, the number of matching events, and their relative score (number of matches divided by their total number of events). Despite having a similar number of matches, MERRA-2, CFSR, and ERA-Interim have different relative scores: $0.72,0.75$, and 0.55 , respectively. ERA-Interim's low relative score indicates that half of its mini-hole events were not found in OMI in contrast to around a third of those in MERRA-2 or CFSR. This indicates that although ERAInterim displays the smallest underestimation of the number of events, many of the events in ERA-Interim are not found in the OMI data. Note that the relatively high scores of JRA-55 and MERRA result from those reanalyses detecting mostly the strongest mini-hole events that are in OMI, whereas the low number of events indicates that those reanalyses do poorly at detecting the smaller events seen in OMI data.

In addition to computing the distance between matching events and their area fraction, we also computed the direction that the events found in the reanalysis fields would have to move to match the position (the latitude-longitude center) of the events found in the OMI data. Figure 7 summarizes the overall direction in which the mini-holes found in the re-
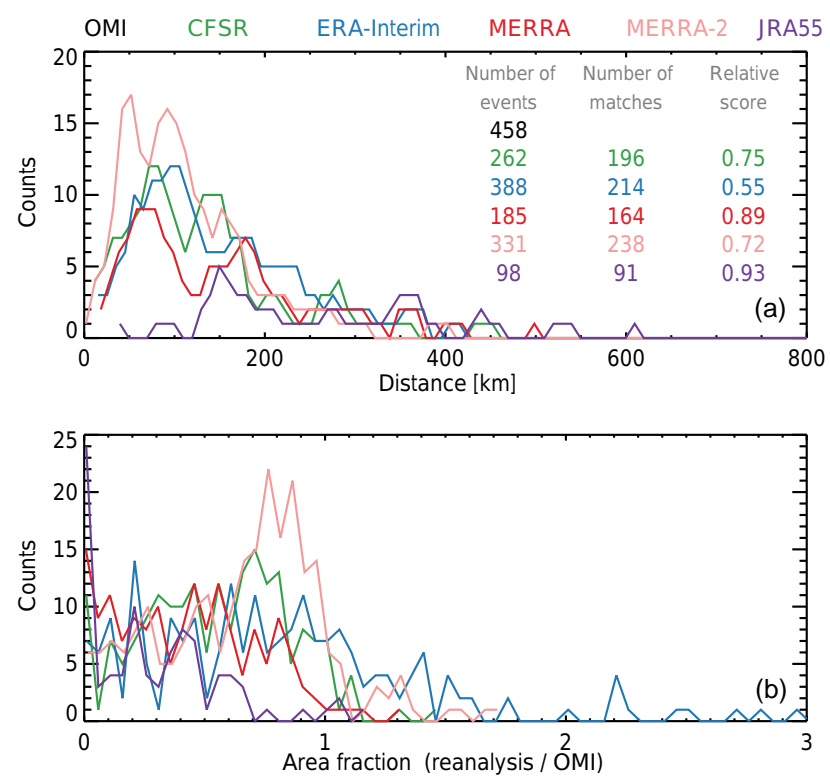

Figure 6. (a) Histograms of the distance between the mini-hole events found in the reanalysis fields and the ones found in OMI data (black, green, blue, red, pink, and purple lines represent OMI, CFSR, ERA-Interim, MERRA, MERRA-2, and JRA-55, respectively). Also shown is the total number of events as well as the number of matches between the events found in OMI and in the reanalyses. (b) Histograms of the area fraction of mini-hole events.

analyses would have to move. The position of each pie slice indicates the direction in a polar coordinate system, its length represents the mean angular distance to be moved, while its color represents the percentage of mini-hole matches in a particular direction. As can be seen, the mini-holes found in the CFSR, MERRA, MERRA-2, and ERA-Interim reanalyses display an eastward bias. That is, most of the time, these mini-holes would have to move westward to match the OMI event's positions. This suggests the possibility that the reanalyses could have westerlies that are too strong, which would shift the reanalysis events eastward. However, investigating this in detail would require extensive study that is beyond the scope of this paper. Note that JRA-55 does not show a particular bias direction; that is, individual JRA-55 mini-holes have to move in different directions to match the OMI events' positions, which is more likely related to their crude treatment of ozone.

\section{Comparison with MLS}

Comparisons with MLS allow us to study the vertical distribution of ozone and temperature during the events. Note that to increase the number of MLS co-locations with the mini-hole events we use day and night data. As a case study, Fig. 8a shows the ozone vertical distribution for MLS during the mini-hole event shown in Fig. 1. Figure 8a also shows 


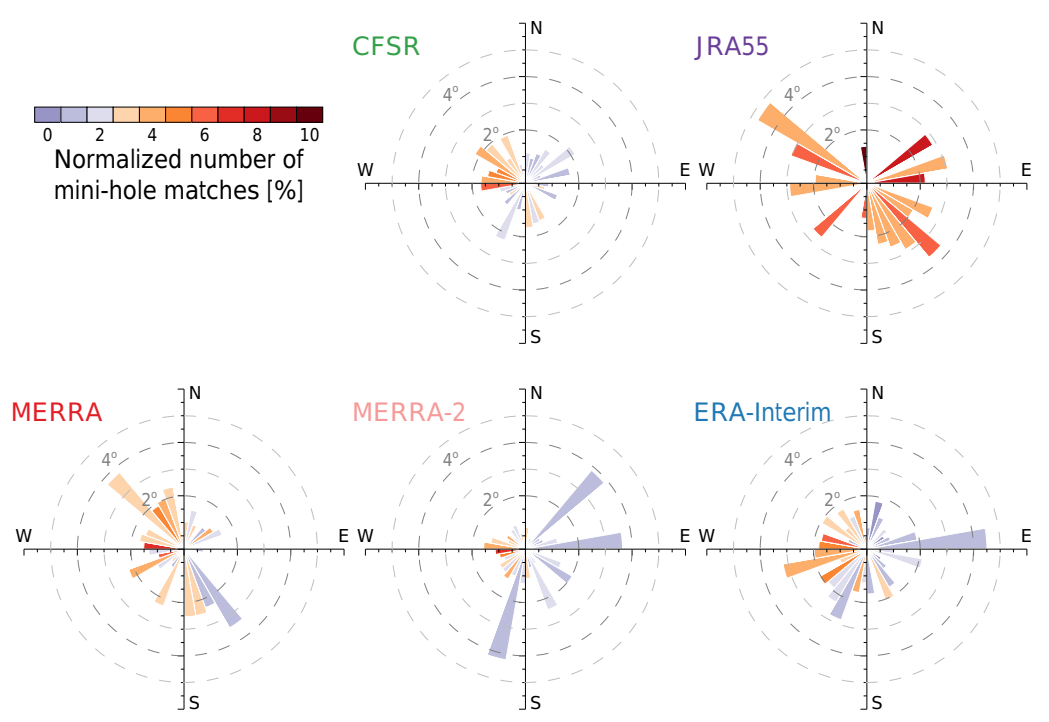

Figure 7. Wind rose plots showing the direction in which events found in the reanalysis fields would have to move to match the events found in OMI data, as well as the mean angular distance to be moved in a particular direction. Gray dashed circles show angular distance. Red/blue indicate relatively high/low normalized number of matches.

a reference profile constructed using profiles over the minihole region from 15 days prior to 15 days after the event, excluding profiles under mini-hole event conditions. The ozone reduction occurs between 200 and $20 \mathrm{hPa}$. Following Keil et al. (2007), the profiles were split into two vertical regimes, an UTLS region (from 300 to $65 \mathrm{hPa}$ ) and a mid-stratospheric (MS) region (from 65 to $1 \mathrm{hPa}$ ). In each of these layers we computed the ozone decrease with respect to the total column ozone. In the MLS data, about two thirds (67\%) of the reduction occurs in the UTLS region while around one third $(33 \%)$ originates in the mid-stratosphere. Using ozone sondes, Keil et al. (2007) found similar values (UTLS: 66\%; MS: $34 \%)$.

In a similar manner, Fig. $8 \mathrm{~b}$ shows the vertical temperature distribution during the 19 January 2006 event. In this case, the mid-stratospheric temperatures and to some extent UTLS temperatures are lower than normal. Low temperatures in the troposphere are usually associated with anticyclonic disturbances, which lead to local uplift of the air (Petzoldt et al., 1994). Using the tropopauses calculated by JETPAC, we computed the mean tropopause altitude during the event as well as during the reference period. The tropopause altitude found in MERRA-2 was $13.4 \mathrm{~km} \pm 3.3$ during the event as opposed to $11.3 \pm 1.6 \mathrm{~km}$ during the reference period, $2.1 \mathrm{~km}$ higher than normal. As indicated in Sect. 1, assuming divergence of air, raising of the tropopause leads to the replacement of relatively ozone-rich air in the column with tropospheric ozone-poor air. To verify that there was net divergence, we estimated the pressure between the isentropes 330 and $500 \mathrm{~K}$; we found $168.4 \mathrm{hPa}$ during the event versus $170.9 \mathrm{hPa}$ during the reference period. As pointed out by Petzoldt et al. (1994), the uplift of air results in adiabatic cooling
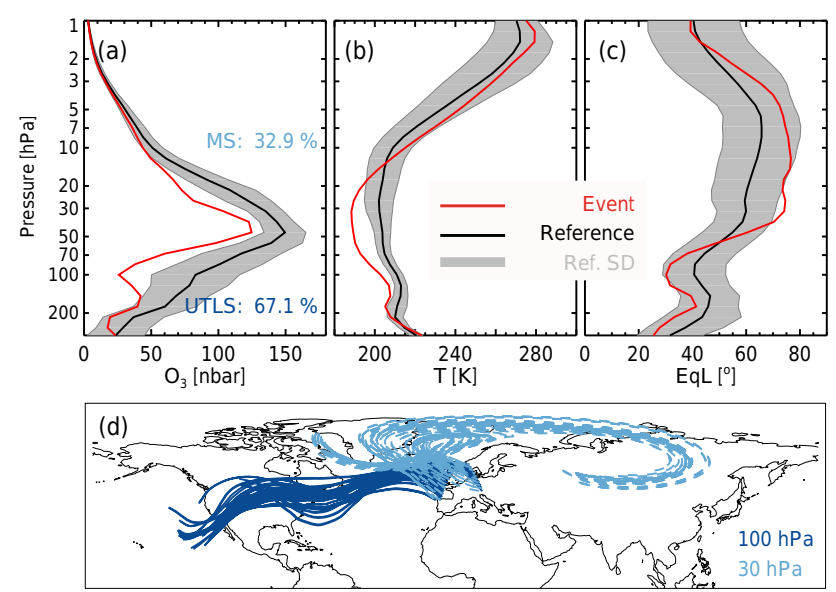

Figure 8. (a) MLS mean ozone vertical profile (red), reference ozone profile (black), and reference standard deviation (gray envelope) during the mini-hole event observed over the UK on 19 January 2006. The reference profile was constructed using profiles over the mini-hole region from 15 days prior to 15 days after the event, excluding profiles under mini-hole event conditions. The percentage ozone reduction with respect to the total column ozone in the UTLS and in the mid-stratosphere is shown in dark and light blue, respectively. (b) As in (a) but for temperature. (c)) As in (a) but for equivalent latitude (EqL) derived from the MERRA-2 reanalysis sampled at the MLS measurement locations. (d) MERRA-2 trajectories launched at the MLS measurement locations in the mini-hole event region at 100 and at $30 \mathrm{hPa}$. 

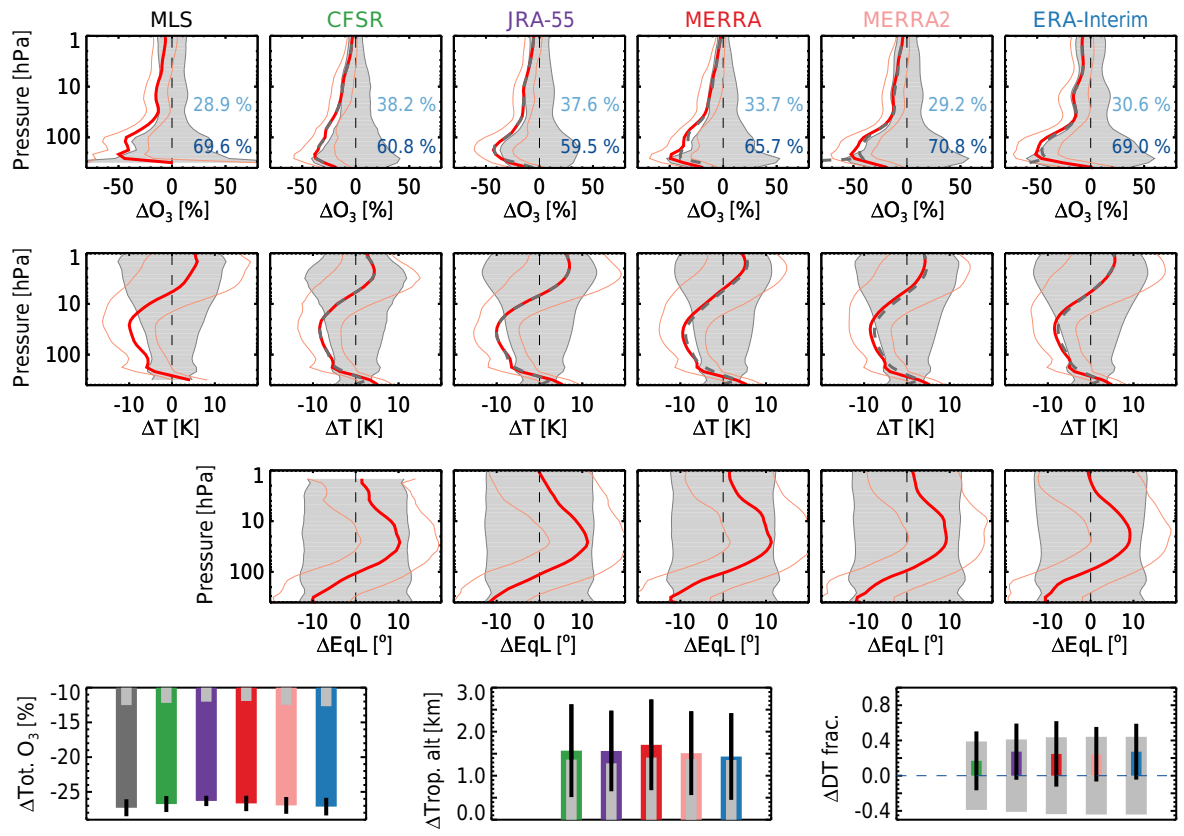

Figure 9. Composite of the difference between the events and the reference values for all mini-hole events found between 2005 and 2014 . The first row shows the ozone vertical profile differences. The ozone composite event difference profile is shown in red, its 1 standard deviation envelope is shown by the thin light red lines, and the gray envelope is the reference composite standard deviation. In the reanalysis panels, the blue dashed lines show the ozone composite event difference when the MLS averaging kernels were applied. The percentage ozone reduction with respect to the total column of ozone in the UTLS and in the mid-stratosphere is shown in dark and light blue, respectively. Similarly, the second row displays the temperature profile differences and the third row displays the EqL vertical profile differences. Lastly, the fourth row shows the percentage difference of the total ozone column, the tropopause altitude difference, and the DT fraction deviations (dark gray, green, blue, red, pink, and purple bars represent the OMI, CFSR, ERA-Interim, MERRA, MERRA-2, and JRA-55 differences, respectively). In this column, light gray bars show the composite reference standard deviation, color bars show the corresponding composite event difference, and the black lines display the composite event difference standard deviation.

of the mid-stratosphere. For example, Hood et al. (2001) analyzed an ensemble of 71 extreme mini-holes (in this case, using a constant 215 DU threshold) and found a nearly linear relationship between the total column ozone and the $30 \mathrm{hPa}$ temperature deviations.

Near the polar vortex edge, low temperatures in the midstratosphere are associated with planetary wave disturbances that are responsible for large-scale ozone redistribution (e.g., Leovy et al., 1985). As an example, Fig. 8c shows the EqL vertical profile derived using MERRA-2 potential vorticity fields. For this, we use the DMPs that, as mentioned before, have been interpolated to the MLS measurement locations. This EqL vertical distribution suggests that in the mid-stratosphere the air parcels originated at polar latitudes. To corroborate this, Fig. 8d shows trajectories launched at $30 \mathrm{hPa}$ from the MLS measurement locations during the mini-hole event. These trajectories were taken from the MLS Lagrangian Trajectory Diagnostic dataset (Livesey et al., 2015), which is a set of 15-day forward and 15-day reverse trajectories launched from a curtain of points along the MLS track. These calculations are based on wind fields and diabatic heating rates taken from the MERRA-2 reanalysis and the advection calculations are based on the algorithm used by Manney et al. (1994). As expected, the majority of the air parcels in the mid-stratosphere originate near the polar vortex. Keil et al. (2007) computed back trajectories for the same event using the Met Office NAME III model and also found that the air in the mid-stratosphere was transported from the polar vortex, where it may have undergone ozone destruction (due to photochemical processes) before reaching the minihole event region.

Figure $8 \mathrm{c}$, as well as the trajectories launched at $100 \mathrm{hPa}$ shown in panel (d), indicates that the air parcels in the UTLS originated at low latitudes. Studies of the characteristics of poleward advection of upper-tropospheric air have shown that such intrusions are associated with Rossby wave breaking in the upper troposphere (Peters and Waugh, 1996). In turn, poleward Rossby wave breaking has been associated with the presence of double tropopauses (DTs) (Pan et al., 2009; Castanheira and Gimeno, 2011; Homeyer et al., 2011; Ungermann et al., 2013). Further, climatological studies have found that DT occurrence in the Northern Hemisphere coincides with zones of storm track cyclogenesis (e.g., Añel et al., 2008; Peevey et al., 2012) and their occurrence frequency shows a strong seasonal variation peaking during winter (Randel et al., 2007; Manney et al., 2014), both char- 
acteristics displayed by the mini-hole events. Using the JETPAC tropopause information, we computed the DT fraction (the area with DTs divided by the total area) during the event as well as during the reference period. During the event, the DT fraction found in MERRA-2 was $0.8 \pm 0.4$, as opposed to $0.61 \pm 0.49$ during the reference period.

Figure 9 displays a composite view of ozone, temperature, and EqL vertical distributions, as well as their total ozone column, tropopause altitude, and DT deviations, for all the events, i.e., not only the matches, found between 2005 and 2014 in the Northern Hemisphere. The number of events is shown in Fig. 6. For ozone and temperature, two composites are shown, one smoothed with the MLS averaging kernels and one without; note that no significant differences were found between the two. The observations and reanalysis fields show a picture that is generally consistent with the one shown in Fig. 8:

- The total ozone column decrease is considerably larger than the natural variability of total ozone column; that is, it is considerably larger than the reference standard deviation of total ozone column.

- On average, around two thirds of the reduction originates in the UTLS and the rest in the mid-stratosphere. MERRA-2 and ERA-Interim show very close agreement with the MLS estimates, presumably because both assimilate, in some capacity, the MLS $\mathrm{O}_{3}$ profiles; however, the other reanalyses also show good agreement.

- Air parcels in the UT originate from low latitudes, while in the mid-stratosphere they arrive from high latitudes.

- Reanalyses show an elevated tropopause during the events. This is consistent with anticyclonic disturbances associated with poleward Rossby wave breaking in the upper troposphere, that is, poleward advection of upper tropospheric air. Note that, overall, net divergence of air was present during the events, with a pressure difference between the 330 and $500 \mathrm{~K}$ isentropes varying from 6.5 to $8.9 \mathrm{hPa}$ less than that in the reference period, depending on the data source analyzed.

- The local uplift of air adiabatically cools the MS, resulting in lower than normal $30 \mathrm{hPa}$ temperatures.

- An increase in DT fraction is seen during the events. However, this increase is considerably smaller than the DT natural variability. This may be because even though DTs may be dynamically coupled with Rossby wave breaking events, DTs occur most frequently above strong cyclonic circulation systems (Randel et al., 2007). That is, mini-hole events are associated with anticyclonic Rossby wave breaking and thus, while some DTs are favorable for mini-hole genesis, many others are not.
As shown in Fig. 9, ozone, temperature, and EqL vertical distributions, as well as the tropopause altitude, during the events are close to, or sometimes inside, the limits of their natural variability. This suggests that mini-hole events are only produced when both the UTLS and mid-stratosphere processes are favorable for reduction of ozone by dynamical processes. To verify this, we investigated whether the UTLS or the MS part of the reduction was enough to produce a mini-hole event, that is a $25 \%$ reduction below the monthly mean. We found that neither in the MLS data nor in the reanalysis fields was the UTLS or the MS reduction enough to produce a single mini-hole event.

\section{Summary}

Dynamical redistribution of ozone can produce large transient and localized ozone reductions, also known as miniholes. In this study we analyze the representation of minihole events in the Northern Hemisphere from several reanalyses (ERA-Interim, MERRA, MERRA-2, CFSR, and JRA55) using data from OMI and MLS. OMI data allow us to compare their geographical representation while MLS data allow us to study their vertical representation.

Several definitions of mini-holes exist in the literature. The results presented here show that the mini-hole frequency as well as their geographical distribution differs vastly depending on their definition. Here, we define mini-hole events as regions where the total column ozone value is less than $25 \%$ below the monthly mean. Further, we only consider as minihole events those ozone fluctuations with an area larger than $200000 \mathrm{~km}^{2}$.

The main findings can be summarized as follows:

- OMI and the reanalysis fields display the same minihole seasonal variability, with more mini-hole events during winter when the atmosphere is more dynamically active.

- OMI and the reanalysis fields display similar mini-hole geographical distributions with mini-holes occurring more frequently over the North Atlantic storm tracks.

- All reanalyses underestimate the number of mini-hole events, with the underestimation ranging from $34 \%$ less for ERA-Interim up to $83 \%$ less for JRA-55. Further, reanalyses typically underestimate the area of the minihole events and most of the time are between 75 and $300 \mathrm{~km}$ away from the events found in OMI.

- Mini-holes found in CFSR, MERRA, MERRA-2, and ERA-Interim reanalyses display an eastward bias with respect to the events found in OMI data. JRA-55 does not show a clear bias direction most likely related to their crude treatment of ozone.

- The composite view of the vertical representation of the events agrees with previously reported mechanisms for 
dynamical mini-hole formation: anticyclonic poleward Rossby wave activity breaking into the UTLS and local uplift of air brings ozone-poor air into the column and is accompanied by equatorward advection of polar air in the mid-stratosphere.

- On average, in the events found in both MLS and the reanalyses, around two thirds of the ozone reduction originates in the UTLS and the rest in the mid-stratosphere.

- Although mini-hole regions typically show more DTs than in surrounding air, the association is not strong because DTs occur most frequently above strong cyclonic circulation systems while mini-holes occur above anticyclonic systems.

In general, MERRA-2 seems to represent mini-holes marginally better than the other reanalyses (see Figs. 6 and 7), likely because MERRA-2 assimilates OMI and MLS ozone throughout the comparison period. CFSR assimilates only SBUV/2 ozone and performs similarly well to ERAInterim, which assimilates OMI and MLS ozone during 2008 and after mid-2009. This suggests that the dynamics produced by the reanalyses are more important than the assimilated ozone fields in reproducing mini-holes.

Due to the mismatch between the mini-holes found in OMI and the mini-holes found in the reanalysis fields, careful attention needs to be paid to ensure that the regions used to study them coincide with regions where the reanalysis fields display mini-hole conditions. That is to say, it is insufficient to identify the mini-hole position in the data and then see what the reanalysis fields do at those exact locations. Rather, one must find the mini-holes in the reanalysis fields, compare if the events are of similar magnitudes, and, if they are, study the meteorological conditions there. This study exemplifies the importance of assessing the reanalyses - for which the satellite data are paramount to cover large areas - before studying atmospheric processes and their variability.

Data availability. All the data and reanalysis fields used in this study are publicly available. Reanalysis fields can be found at NASA GMAO, ECMWF, JMA, and NCEP websites. MLS and OMI data are available from the NASA Goddard Space Flight Center Earth Sciences (GES) Data and Information Services Center (http://disc.sci.gsfc.nasa.gov/).

Competing interests. The authors declare that they have no conflict of interest.

Special issue statement. This article is part of the special issue "The SPARC Reanalysis Intercomparison Project (S-RIP) (ACP/ESSD inter-journal SI)". It is not associated with a conference.
Acknowledgements. We thank the JPL MLS team, especially Brian Knosp and Ryan Fuller, as well as Zachary Lawrence for help in obtaining, managing, and processing the reanalysis datasets; Nathaniel Livesey for supplying the MLS Lagrangian Trajectory Diagnostic dataset; NASA's GMAO, ECMWF, JMA, and NCEP for providing their reanalysis data; and Michaela Hegglin for helpful discussions. Work at the Jet Propulsion Laboratory, California Institute of Technology, was done under contract with the National Aeronautics and Space Administration.

Edited by: William Lahoz

Reviewed by: two anonymous referees

\section{References}

Añel, J. A., Antuña, J. C., de la Torre, L., Castanheira, J. M. and Gimeno, L.: Climatological features of global multiple tropopause events, J. Geophys. Res.-Atmos., 113, d00B08, https://doi.org/10.1029/2007JD009697, 2008.

Allen, D. R. and Nakamura, N.: Dynamical reconstruction of the record low column ozone over Europe on 30 November 1999, Geophys. Res. Lett., 29, 76-1-76-4, https://doi.org/10.1029/2002GL014935, 2002.

Antón, M., López, M., Vilaplana, J. M., Kroon, M., McPeters, R., Bañón, M., and Serrano, A.: Validation of OMI-TOMS and OMIDOAS total ozone column using five Brewer spectroradiometers at the Iberian peninsula, J. Geophys. Res.-Atmos., 114, d14307, https://doi.org/10.1029/2009JD012003, 2009.

Balis, D., Kroon, M., Koukouli, M. E., Brinksma, E. J., Labow, G., Veefkind, J. P., and McPeters, R. D.: Validation of Ozone Monitoring Instrument total ozone column measurements using Brewer and Dobson spectrophotometer groundbased observations, J. Geophys. Res.-Atmos., 112, d24S46, https://doi.org/10.1029/2007JD008796, 2007.

Bhartia, P. K. and Wellemeyer, C.: TOMS-V8 total O3 algorithm, in OMI Algorithm Theoretical Basis Document, vol. II, OMI Ozone Products, ATBD-OMI-02, available at: https://eospso.gsfc.nasa. gov/sites/default/files/atbd/ATBD-OMI-02.pdf (last access: 10 April 2017), 2002.

Bojkov, R. D. and Balis, D. S.: Characteristics of episodes with extremely low ozone values in the northern middle latitudes 1957-2000, Ann. Geophys., 19, 797-807, https://doi.org/10.5194/angeo-19-797-2001, 2001.

Bosilovich, M., Akella, S., Coy, L., Cullather, R., Draper, C., Gelaro, R., Kovach, R., Liu, Q., Molod, A., Norris, P., Wargan, K., Chao, W., Reichle, R., Takacs, L., Vikhliaev, Y., Bloom, S., Collow, A., Firth, S., Labow, G., Partyka, G., Pawson, S., Reale, O., Schubert, S. D., and Suarez, M.: MERRA-2: Initial evaluation of the climate, NASA Tech. Rep Series on Global Modeling and Data Assimilation, 43, 2015.

Butchart, N. and Remsberg, E.: The Area of the Stratospheric Polar Vortex as a Diagnostic for Tracer Transport on an Isentropic Surface, J. Atmos. Sci., 43, 1319-1339, https://doi.org/10.1175/15200469(1986)043<1319:TAOTSP>2.0.CO;2, 1986

Canziani, P. O., Compagnucci, R. H., Bischoff, S. A., and Legnani, W. E.: A study of impacts of tropospheric synoptic processes on the genesis and evolution of extreme total ozone anomalies over 
southern South America, J. Geophys. Res.-Atmos., 107, 4741, https://doi.org/10.1029/2001JD000965, 2002.

Cariolle, D. and Déqué, M.: Southern hemisphere medium-scale waves and total ozone disturbances in a spectral general circulation model, J. Geophys. Res.-Atmos., 91, 10825-10846, https://doi.org/10.1029/JD091iD10p10825, 1986.

Cariolle, D. and Teyssèdre, H.: A revised linear ozone photochemistry parameterization for use in transport and general circulation models: multi-annual simulations, Atmos. Chem. Phys., 7, 21832196, https://doi.org/10.5194/acp-7-2183-2007, 2007.

Castanheira, J. M. and Gimeno, L.: Association of double tropopause events with baroclinic waves, J. Geophys. Res.Atmos., 116, d19113, https://doi.org/10.1029/2011JD016163, 2011.

Courtier, P., Thepaut, J.-J., and Hollingsworth, A.: A strategy for operational implementation of 4D-Var, using an incremental approach, Q. J. Roy. Meteor. Soc., 120, 1367-1388, 1994.

Davis, S. M., Hegglin, M. I., Fujiwara, M., Dragani, R., Harada, Y., Kobayashi, C., Long, C., Manney, G. L., Nash, E., Potter, G. L., Tegtmeier, S., Wang, T., Wargan, K., and Wright, J. S.: Assessment of upper tropospheric and stratospheric water vapour and ozone in reanalyses as part of S-RIP, Atmos. Chem. Phys. Discuss., https://doi.org/10.5194/acp-2017-377, in review, 2017.

Dee, D. P., Uppala, S. M., Simmons, A. J., Berrisford, P., Poli, P., Kobayashi, S., Andrae, U., Balmaseda, M. A., Balsamo, G., Bauer, P., Bechtold, P., Beljaars, A. C. M., van de Berg, L., Bidlot, J., Bormann, N., Delsol, C., Dragani, R., Fuentes, M., Geer, A. J., Haimberger, L., Healy, S. B., Hersbach, H., Hølm, E. V., Isaksen, L., Kållberg, P., Köhler, M., Matricardi, M., McNally, A. P., Monge-Sanz, B. M., Morcrette, J.-J., Park, B.-K., Peubey, C., de Rosnay, P., Tavolato, C., Thépaut, J.-N., and Vitart, F.: The ERA-Interim reanalysis: configuration and performance of the data assimilation system, Q. J. Roy. Meteor. Soc., 137, 553-597, https://doi.org/10.1002/qj.828, 2011.

Dethof, A. and Hólm, E. V.: Ozone assimilation in the ERA-40 reanalysis project, Q. J. Roy. Meteor. Soc., 130, 2851-2872, https://doi.org/10.1256/qj.03.196, 2004.

Dobson, G. M. B., Harrison, D. N., and Lawrence, J.: Measurements of the Amount of Ozone in the Eart's Atmosphere and Its Relation to Other Geophysical Conditions. Part III, P. R. Soc. A, 122, 456-486, https://doi.org/10.1098/rspa.1929.0034, 1929.

Froidevaux, L., Jiang, Y. B., Lambert, A., Livesey, N. J., Read, W. G., Waters, J. W., Browell, E. V., Hair, J. W., Avery, M. A., McGee, T. J., Twigg, L. W., Sumnicht, G. K., Jucks, K. W., Margitan, J. J., Sen, B., Stachnik, R. A., Toon, G. C., Bernath, P. F., Boone, C. D., Walker, K. A., Filipiak, M. J., Harwood, R. S., Fuller, R. A., Manney, G. L., Schwartz, M. J., Daffer, W. H., Drouin, B. J., Cofield, R. E., Cuddy, D. T., Jarnot, R. F., Knosp, B. W., Perun, V. S., Snyder, W. V., Stek, P. C., Thurstans, R. P., and Wagner, P. A.: Validation of Aura Microwave Limb Sounder stratospheric ozone measurements, J. Geophys. Res.-Atmos., 113, d15S20, https://doi.org/10.1029/2007JD008771, 2008.

Fujiwara, M., Wright, J. S., Manney, G. L., Gray, L. J., Anstey, J., Birner, T., Davis, S., Gerber, E. P., Harvey, V. L., Hegglin, M. I., Homeyer, C. R., Knox, J. A., Krüger, K., Lambert, A., Long, C. S., Martineau, P., Molod, A., Monge-Sanz, B. M., Santee, M. L., Tegtmeier, S., Chabrillat, S., Tan, D. G. H., Jackson, D. R., Polavarapu, S., Compo, G. P., Dragani, R., Ebisuzaki, W., Harada, Y., Kobayashi, C., McCarty, W., Onogi, K., Paw- son, S., Simmons, A., Wargan, K., Whitaker, J. S., and Zou, C.-Z.: Introduction to the SPARC Reanalysis Intercomparison Project (S-RIP) and overview of the reanalysis systems, Atmos. Chem. Phys., 17, 1417-1452, https://doi.org/10.5194/acp17-1417-2017, 2017.

Homeyer, C. R., Bowman, K. P., and Pan, L. L.: Extratropical tropopause transition layer characteristics from highresolution sounding data, J. Geophys. Res.-Atmos., 115, d13108, https://doi.org/10.1029/2009JD013664, 2010.

Homeyer, C. R., Bowman, K. P., Pan, L. L., Atlas, E. L., Gao, R.-S., and Campos, T. L.: Dynamical and chemical characteristics of tropospheric intrusions observed during START08, J. Geophys. Res.-Atmos., 116, d06111, https://doi.org/10.1029/2010JD015098, 2011.

Hood, L. L., Soukharev, B. E., Fromm, M., and McCormack, J. P.: Origin of extreme ozone minima at middle to high northern latitudes, J. Geophys. Res.-Atmos., 106, 20925-20940, https://doi.org/10.1029/2001JD900093, 2001.

Hubert, D., Lambert, J.-C., Verhoelst, T., Granville, J., Keppens, A., Baray, J.-L., Bourassa, A. E., Cortesi, U., Degenstein, D. A., Froidevaux, L., Godin-Beekmann, S., Hoppel, K. W., Johnson, B. J., Kyrölä, E., Leblanc, T., Lichtenberg, G., Marchand, M., McElroy, C. T., Murtagh, D., Nakane, H., Portafaix, T., Querel, R., Russell III, J. M., Salvador, J., Smit, H. G. J., Stebel, K., Steinbrecht, W., Strawbridge, K. B., Stübi, R., Swart, D. P. J., Taha, G., Tarasick, D. W., Thompson, A. M., Urban, J., van Gijsel, J. A. E., Van Malderen, R., von der Gathen, P., Walker, K. A., Wolfram, E., and Zawodny, J. M.: Ground-based assessment of the bias and long-term stability of 14 limb and occultation ozone profile data records, Atmos. Meas. Tech., 9, 2497-2534, https://doi.org/10.5194/amt-9-2497-2016, 2016.

Iwao, K. and Hirooka, T.: Dynamical quantifications of ozone minihole formation in both hemispheres, J. Geophys. Res.-Atmos., 111, d02104, https://doi.org/10.1029/2005JD006333, 2006.

James, P. M.: A climatology of ozone mini-holes over the northern hemisphere, Int. J. Climatol., 18, 1287-1303, https://doi.org/10.1002/(SICI)10970088(1998100)18:12<1287::AID-JOC315>3.0.CO;2-4, 1998a.

James, P. M.: An interhemispheric comparison of ozone mini-hole climatologies, Geophys. Res. Lett., 25, 301-304, 1998b.

James, P. M. and Peters, D.: The Lagrangian structure of ozone mini-holes and potential vorticity anomalies in the Northern Hemisphere, Ann. Geophys., 20, 835-846, https://doi.org/10.5194/angeo-20-835-2002, 2002.

James, P. M., Peters, D., and Waugh, D. W.: Very low ozone episodes due to polar vortex displacement, Tellus B, 52, 11231137, https://doi.org/10.3402/tellusb.v52i4.17089, 2000.

Jiang, Y. B., Froidevaux, L., Lambert, A., Livesey, N. J., Read, W. G., Waters, J. W., Bojkov, B., Leblanc, T., McDermid, I. S., Godin-Beekmann, S., Filipiak, M. J., Harwood, R. S., Fuller, R. A., Daffer, W. H., Drouin, B. J., Cofield, R. E., Cuddy, D. T., Jarnot, R. F., Knosp, B. W., Perun, V. S., Schwartz, M. J., Snyder, W. V., Stek, P. C., Thurstans, R. P., Wagner, P. A., Allaart, M., Andersen, S. B., Bodeker, G., Calpini, B., Claude, H., Coetzee, G., Davies, J., De Backer, H., Dier, H., Fujiwara, M., Johnson, B., Kelder, H., Leme, N. P., König-Langlo, G., Kyro, E., Laneve, G., Fook, L. S., Merrill, J., Morris, G., Newchurch, M., Oltmans, S., Parrondos, M. C., Posny, F., Schmidlin, F., Skrivankova, P., Stubi, R., Tarasick, D., Thompson, A., Thouret, V., Viatte, P., 
Vömel, H., von Der Gathen, P., Yela, M., and Zablocki, G.: Validation of Aura Microwave Limb Sounder Ozone by ozonesonde and lidar measurements, J. Geophys. Res.-Atmos., 112, d24S34, https://doi.org/10.1029/2007JD008776, 2007.

Keil, M., Jackson, D. R., and Hort, M. C.: The January 2006 low ozone event over the UK, Atmos. Chem. Phys., 7, 961-972, https://doi.org/10.5194/acp-7-961-2007, 2007.

Kobayashi, S., Ota, Y., Harada, Y., Ebita, A., Moriya, M., Onoda, H., Onogi, K., Kamahori, H., Kobayashi, C., Endo, H., Miyaoka, K., and Takahashi, K.: The JRA-55 Reanalysis: General Specifications and Basic Characteristics, J. Meteorol. Soc. Jpn., 93, 5-48, https://doi.org/10.2151/jmsj.2015-001, 2015.

Koch, G., Wernli, H., Schwierz, C., Staehelin, J., and Peter, T.: A composite study on the structure and formation of ozone miniholes and minihighs over central Europe, Geophys. Res. Lett., 32, 112810, https://doi.org/10.1029/2004GL022062, 2005.

Kroon, M., Petropavlovskikh, I., Shetter, R., Hall, S., Ullmann, K., Veefkind, J. P., McPeters, R. D., Browell, E. V., and Levelt, P. F.: OMI total ozone column validation with Aura-AVE CAFS observations, J. Geophys. Res.-Atmos., 113, d15S13, https://doi.org/10.1029/2007JD008795, 2008.

Lawless, A. S.: A note on the analysis error associated with 3D-FGAT, Q. J. Roy. Meteor. Soc., 136, 1094-1098, https://doi.org/10.1002/qj.619, 2010.

Leovy, C. B., Hitchman, M. H., Remsberg, E. E., Russell, J. M., Gordley, L. L., Gille, J. C., and Lyjak, L. V.: Transport of Ozone in the Middle Stratosphere: Evidence for Planetary Wave Breaking, J. Atmos. Sci., 42, 230-244, https://doi.org/10.1175/15200469(1985)042<0230:TOOITM>2.0.CO;2, 1985.

Levelt, P. F., Hilsenrath, E., Leppelmeier, G. W., van den Oord, G. H. J., Bhartia, P. K., Tamminen, J., de Haan, J. F., and Veefkind, J. P.: Science objectives of the ozone monitoring instrument, IEEE T. Geosci. Remote Sens., 44, 1199-1208, https://doi.org/10.1109/TGRS.2006.872336, 2006.

Livesey, N. J., Snyder, W. V., Read, W. G., and Wagner, P. A.: Retrieval algorithms for the EOS Microwave limb sounder (MLS), IEEE T. Geosci. Remote Sens., 44, 1144-1155, https://doi.org/10.1109/TGRS.2006.872327, 2006.

Livesey, N. J., Filipiak, M. J., Froidevaux, L., Read, W. G., Lambert, A., Santee, M. L., Jiang, J. H., Pumphrey, H. C., Waters, J. W., Cofield, R. E., Cuddy, D. T., Daffer, W. H., Drouin, B. J., Fuller, R. A., Jarnot, R. F., Jiang, Y. B., Knosp, B. W., Li, Q. B., Perun, V. S., Schwartz, M. J., Snyder, W. V., Stek, P. C., Thurstans, R. P., Wagner, P. A., Avery, M., Browell, E. V., Cammas, J.P., Christensen, L. E., Diskin, G. S., Gao, R.-S., Jost, H.-J., Loewenstein, M., Lopez, J. D., Nedelec, P., Osterman, G. B., Sachse, G. W., and Webster, C. R.: Validation of Aura Microwave Limb Sounder $\mathrm{O}_{3}$ and $\mathrm{CO}$ observations in the upper troposphere and lower stratosphere, J. Geophys. Res.-Atmos., 113, d15S02, https://doi.org/10.1029/2007JD008805, 2008.

Livesey, N. J., Santee, M. L., and Manney, G. L.: A Matchbased approach to the estimation of polar stratospheric ozone loss using Aura Microwave Limb Sounder observations, Atmos. Chem. Phys., 15, 9945-9963, https://doi.org/10.5194/acp15-9945-2015, 2015.

Livesey, N. J., Read, W., Wagner, P. A. Froidevaux, L., Lambert, A., Manney, G. L., Millán Valle, L., Pumphrey, H. C., Santee, M. L., Schwartz, M. J., Wang, S., Fuller, R. A., Jarnot, R. F., Knosp, B. W., and Martinez, E.: Version 4.2x Level 2 data quality and description document, JPL D-33509 Rev. C, available at: http: //mls.jpl.nasa.gov (last access: 10 April 2017), 2017.

Mangold, A., Grooß, J.-U., De Backer, H., Kirner, O., Ruhnke, R., and Müller, R.: A model study of the January 2006 low total ozone episode over Western Europe and comparison with ozone sonde data, Atmos. Chem. Phys., 9, 6429-6451, https://doi.org/10.5194/acp-9-6429-2009, 2009.

Manney, G. L., Zurek, R. W., Gelman, M. E., Miller, A. J., and Nagatani, R.: The anomalous Arctic lower stratospheric polar vortex of 1992-1993, Geophys. Res. Lett., 21, 2405-2408, https://doi.org/10.1029/94GL02368, 1994.

Manney, G. L., Daffer, W. H., Zawodny, J. M., Bernath, P. F., Hoppel, K. W., Walker, K. A., Knosp, B. W., Boone, C., Remsberg, E. E., Santee, M. L., Harvey, V. L., Pawson, S., Jackson, D. R., Deaver, L., McElroy, C. T., McLinden, C. A., Drummond, J. R., Pumphrey, H. C., Lambert, A., Schwartz, M. J., Froidevaux, L., McLeod, S., Takacs, L. L., Suarez, M. J., Trepte, C. R., Cuddy, D. C., Livesey, N. J., Harwood, R. S., and Waters, J. W.: Solar occultation satellite data and derived meteorological products: Sampling issues and comparisons with Aura Microwave Limb Sounder, J. Geophys. Res.-Atmos., 112, d24S50, https://doi.org/10.1029/2007JD008709, 2007.

Manney, G. L., Hegglin, M. I., Daffer, W. H., Santee, M. L., Ray, E. A., Pawson, S., Schwartz, M. J., Boone, C. D., Froidevaux, L., Livesey, N. J., Read, W. G., and Walker, K. A.: Jet characterization in the upper troposphere/lower stratosphere (UTLS): applications to climatology and transport studies, Atmos. Chem. Phys., 11, 6115-6137, https://doi.org/10.5194/acp11-6115-2011, 2011.

Manney, G. L., Hegglin, M., Daffer, W. H., Schwartz, M. J., Santee, M. L., and Pawson, S.: Climatology of Upper TroposphericLower Stratospheric (UTLS) Jets and Tropopauses in MERRA, J. Climate, 27, 3248-3271, https://doi.org/10.1175/JCLI-D-1300243.1, 2014.

Martínez-Lozano, J. A., Utrillas, M. P., Núñez, J. A., Tamayo, J., Marín, M. J., Esteve, A. R., Cañada, J., and Moreno, J. C.: Ozone mini-holes over Valencia (Spain) and their influence on the UV erythemal radiation, Int. J. Climatol., 31, 1554-1566, https://doi.org/10.1002/joc.2173, 2011.

McCormack, J. P., Eckermann, S. D., Siskind, D. E., and McGee, T. J.: CHEM2D-OPP: A new linearized gas-phase ozone photochemistry parameterization for high-altitude NWP and climate models, Atmos. Chem. Phys., 6, 4943-4972, https://doi.org/10.5194/acp-6-4943-2006, 2006.

McPeters, R., Kroon, M., Labow, G., Brinksma, E., Balis, D., Petropavlovskikh, I., Veefkind, J. P., Bhartia, P. K., and Levelt, P. F.: Validation of the Aura Ozone Monitoring Instrument total column ozone product, J. Geophys. Res.-Atmos., 113, d15S14, https://doi.org/10.1029/2007JD008802, 2008.

Meetham, A. R. and Dobson, G. M. B.: The correlation of the amount of ozone with other characteristics of the atmosphere, Q. J. Roy. Meteor. Soc., 63, 289-307, https://doi.org/10.1002/qj.49706327102, 1937.

Newman, P. A., Lait, L. R., and Schoeberl, M. R.: The morphology and meteorology of southern hemisphere spring total ozone mini-holes, Geophys. Res. Lett., 15, 923-926, https://doi.org/10.1029/GL015i008p00923, 1988.

Orsolini, Y., Cariolle, D., and Déqué, M.: Ridge formation in the lower stratosphere and its influence on ozone trans- 
port: A general circulation model study during late January 1992, J. Geophys. Res.-Atmos., 100, 11113-11135, https://doi.org/10.1029/94JD01930, 1995.

Pan, L. L., Randel, W. J., Gille, J. C., Hall, W. D., Nardi, B., Massie, S., Yudin, V., Khosravi, R., Konopka, P., and Tarasick, D.: Tropospheric intrusions associated with the secondary tropopause, J. Geophys. Res.-Atmos., 114, d10302, https://doi.org/10.1029/2008JD011374, 2009.

Peevey, T. R., Gille, J. C., Randall, C. E., and Kunz, A.: Investigation of double tropopause spatial and temporal global variability utilizing High Resolution Dynamics Limb Sounder temperature observations, J. Geophys. Res.-Atmos., 117, d01105, https://doi.org/10.1029/2011JD016443, 2012.

Peters, D. and Waugh, D. W.: Influence of Barotropic Shear on the Poleward Advection of Upper-Tropospheric Air, J. Atmos. Sci., 53, 3013-3031, https://doi.org/10.1175/15200469(1996)053<3013:IOBSOT>2.0.CO;2, 1996.

Peters, D., Egger, J., and Entzian, G.: Dynamical aspects of ozone mini-hole formation, Meteorol. Atmos. Phys., 55, 205-214, https://doi.org/10.1007/BF01029827, 1995.

Petzoldt, K., Naujokat, B., and Neugebohren, K.: Correlation between stratospheric temperature, total ozone, and tropospheric weather systems, Geophys. Res. Lett., 21, 1203-1206, https://doi.org/10.1029/93GL03020, 1994.

Randel, W. J., Seidel, D. J., and Pan, L. L.: Observational characteristics of double tropopauses, J. Geophys. Res.-Atmos., 112, d07309, https://doi.org/10.1029/2006JD007904, 2007.

Reed, R. J.: The role of vertical motions in ozone weather relationships, J. Meteorol., 7, 263-267, https://doi.org/10.1175/15200469(1950)007<0263:TROVMI>2.0.CO;2, 1950.

Rienecker, M. M., Suarez, M. J., Todling, R., Bacmeister, J., Takacs, L., Liu, H.-C., Gu, W., Sienkiewicz, M., Koster, R. D., Gelaro, R., Stajner, I., and Nielsen, J. E.: The GEOS-5 Data Assimilation System - Documentation of versions 5.0.1, 5.1.0, and 5.2.0, NASA Tech. Rep. Series on Global Modeling and Data Assimilation, 27, 92 pp., 2008.

Rienecker, M. M., Suarez, M. J., Gelaro, R., Todling, R., Bacmeister, J., Liu, E., Bosilovich, M. G., Schubert, S. D., Takacs, L., Kim, G.-K., Bloom, S., Chen, J., Collins, D., Conaty, A., da Silva, A., Gu, W., Joiner, J., Koster, R. D., Lucchesi, R., Molod, A., Owens, T., Pawson, S., Pegion, P., Redder, C. R., Reichle, R., Robertson, F. R., Ruddick, A. G., Sienkiewicz, M., and Woollen, J.: MERRA: NASA's Modern-Era Retrospective Analysis for Research and Applications, J. Climate, 24, 3624-3648, https://doi.org/10.1175/jcli-d-11-00015.1, 2011.

Saha, S., Moorthi, S., Pan, H.-L., Wu, X., Wang, J., Nadiga, S., Tripp, P., Kistler, R., Woollen, J., Behringer, D., Liu, H., Stokes, D., Grumbine, R., Gayno, G., Wang, J., Hou, Y.-T., Chuang, H.Y., Juang, H.-M. H., Sela, J., Iredell, M., Treadon, R., Kleist, D., Van Delst, P., Keyser, D., Derber, J., Ek, M., Meng, J., Wei, H., Yang, R., Lord, S., Van Den Dool, H., Kumar, A., Wang, W., Long, C., Chelliah, M., Xue, Y., Huang, B., Schemm, J.-K., Ebisuzaki, W., Lin, R., Xie, P., Chen, M., Zhou, S., Higgins, W., Zou, C.-Z., Liu, Q., Chen, Y., Han, Y., Cucurull, L., Reynolds, R. W., Rutledge, G., and Goldberg, M.: The NCEP Climate Forecast System Reanalysis, B. Am. Meteorol. Soc., 91, 1015-1057, https://doi.org/10.1175/2010bams3001.1, 2010.

Salby, M. L. and Callaghan, P. F.: Fluctuations of total ozone and their relationship to stratospheric air motions, J. Geophys. Res.-
Atmos., 98, 2715-2727, https://doi.org/10.1029/92JD01814, 1993.

Schoeberl, M. R., Douglass, A. R., Hilsenrath, E., Bhartia, P. K., Beer, R., Waters, J. W., Gunson, M. R., Froidevaux, L., Gille, J. C., Barnett, J. J., Levelt, P. F., and DeCola, P.: Overview of the EOS aura mission, IEEE T. Geosci. Remote Sens., 44, 10661074, https://doi.org/10.1109/TGRS.2005.861950, 2006.

Schwartz, M. J., Lambert, A., Manney, G. L., Read, W. G., Livesey, N. J., Froidevaux, L., Ao, C. O., Bernath, P. F., Boone, C. D., Cofield, R. E., Daffer, W. H., Drouin, B. J., Fetzer, E. J., Fuller, R. A., Jarnot, R. F., Jiang, J. H., Jiang, Y. B., Knosp, B. W., Krüger, K., Li, J.-L. F., Mlynczak, M. G., Pawson, S., Russell, J. M., Santee, M. L., Snyder, W. V., Stek, P. C., Thurstans, R. P., Tompkins, A. M., Wagner, P. A., Walker, K. A., Waters, J. W., and Wu, D. L.: Validation of the Aura Microwave Limb Sounder temperature and geopotential height measurements, J. Geophys. Res.-Atmos., 113, d15S11, https://doi.org/10.1029/2007JD008783, 2008.

Shibata, K., Deushi, M., Sekiyama, T. T., and Yoshimura, H.: Development of an MRI chemical transport model for the study of stratospheric chemistry, Pap. Geophys. Meteor., 55, 75-119, 2010 .

Teitelbaum, H., Moustaoui, M., Van Velthoven, P. F. J., and Kelder, H.: Decrease of total ozone at low latitudes in the southern hemisphere by a combination of linear and nonlinear processes, Q. J. Roy. Meteor. Soc., 124, 2625-2644, https://doi.org/10.1002/qj.49712455205, 1998.

Ungermann, J., Pan, L. L., Kalicinsky, C., Olschewski, F., Knieling, P., Blank, J., Weigel, K., Guggenmoser, T., Stroh, F., Hoffmann, L., and Riese, M.: Filamentary structure in chemical tracer distributions near the subtropical jet following a wave breaking event, Atmos. Chem. Phys., 13, 10517-10534, https://doi.org/10.5194/acp-13-10517-2013, 2013.

Vaughan, G. and Price, J. D.: On the relation between total ozone and meteorology, Q. J. Roy. Meteor. Soc., 117, 1281-1298, https://doi.org/10.1002/qj.49711750208, 1991.

Veefkind, J. P., de Haan, J. F., Brinksma, E. J., Kroon, M., and Levelt, P. F.: Total Ozone From the Ozone Monitoring Instrument (OMI) Using the DOAS Technique, IEEE T. Geosci. Remote Sens., 44, 1239-1244, 2006.

Wargan, K., Labow, G., Frith, S., Pawson, S., Livesey, N., and Partyka, G.: Evaluation of the Ozone Fields in NASA's MERRA-2 Reanalysis, J. Climate, 30, 2961-2988, https://doi.org/10.1175/JCLI-D-16-0699.1, 2017.

Waters, J. W., Froidevaux, L., Harwood, R. S., Jarnot, R. F., Pickett, H. M., Read, W. G., Siegel, P. H., Cofield, R. E., Filipiak, M. J., Flower, D. A., Holden, J. R., Lau, G. K., Livesey, N. J., Manney, G. L., Pumphrey, H. C., Santee, M. L., Wu, D. L., Cuddy, D. T., Lay, R. R., Loo, M. S., Perun, V. S., Schwartz, M. J., Stek, P. C., Thurstans, R. P., Boyles, M. A., Chandra, K. M., Chavez, M. C., Chen, G.-S., Chudasama, B. V., Dodge, R., Fuller, R. A., Girard, M. A., Jiang, J. H., Jiang, Y., Knosp, B. W., LaBelle, R. C., Lam, J. C., Lee, K. A., Miller, D., Oswald, J. E., Patel, N. C., Pukala, D. M., Quintero, O., Scaff, D. M., Snyder, W. V., Tope, M. C., Wagner, P. A., and Walch, M. J.: The Earth observing system microwave limb sounder (EOS MLS) on the aura Satellite, IEEE T. Geosci. Remote Sens., 44, 1075-1092, https://doi.org/10.1109/TGRS.2006.873771, 2006. 